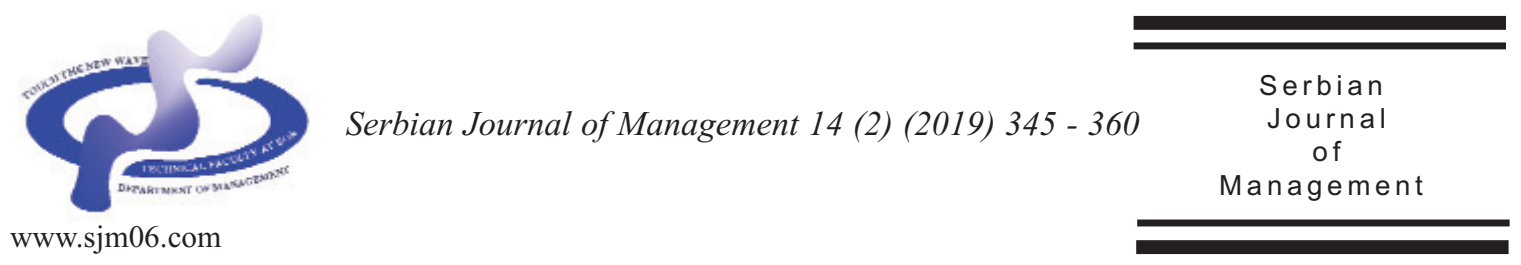

\title{
DOMINANT FACTORS OF SMES FAILURE - MULTIGROUP CONFIRMATORY FACTOR ANALYSIS
}

\author{
Isidora Miloševič* ${ }^{*}$ Ivan Mihajlović and Anđelka Stojanović \\ University of Belgrade, Technical Faculty in Bor, Engineering Management Department, \\ Vojske Jugoslavije 12, Bor, Serbia
}

(Received 10 August 2019; accepted 15 October 2019)

\begin{abstract}
The paper aims to provide empirical clarification over some key failure factors of Small and Medium-sized Enterprises (SMEs), and also analysis of the similarities and differences in factors' relations in the Republic of Serbia and Visegrad countries. The SMEs' failures factors have been accessed from the point of view of SMEs owners and managers whose opinions were collected through a questionnaire disseminated in five countries (Hungary, Czech Republic, Slovak Republic, Poland and the Republic of Serbia). On the other hand, for the research presented in this paper, the data from Hungary, the Czech Republic and the Republic of Serbia were used. The structural equation model was developed and analyzed to confirm the reliability of the conceptual model, using multi-group confirmatory factor analysis (MGCFA) for comparative measurements on the observed data from different countries. The result showed the existence of differences in opinions of SMEs owners and managers concerning failure factors in examined countries.
\end{abstract}

Keywords: Small and medium sized enterprises, failure factors, multi-group analysis

\section{INTRODUCTION}

The issue of failure of the Small and Medium sized Enterprises (SMEs) is principally vital in transitional countries. The SMEs sector is the largest segment of the national economies with great percent of the total number of enterprises, major in employing large numbers of people and a significantly contributes to Gross Domestic Product (GDP). In light of the global economic crisis and recovery period, the SMEs continued to create new jobs and employ (Kalak \& Hudson, 2016), which further emphasizes the importance of the SME sector. On the other hand, intense

* Corresponding author: imilosevic@tfbor.bg.ac.rs

DOI: $10.5937 /$ sjm14-23536 
changes in the global economy and the necessity of fast adaptation on consumers' demands put many pressures and challenges for SMEs. They face a weak financial position and reduced possibilities of accessing the financial resources (Guptaa \& Gregoriou, 2018) and are forced to cease business operations and declare bankruptcy. In reality, business failures are not uncommon. Statistics in the USA show that even $20 \%$ of established SMEs fail in the first year of operations and only $50 \%$ survive after the fifth year (U.S. Small Business Administration, 2018). Similar statistics are in European countries (Eurostat, 2018). These numbers are the reason for the great interests of academics, governments and practitioners for this topic. Two directions can be pointed out as important in dealing with SMEs failure. One is the main reasons for the failure of one SME, and another is the capability and possibility to recover after the failure.

The transition is a process that differs from country to country and faces different conditions in the surrounding. The changes are being made in the political, institutional and economic areas and trigger the creation of a wide range of business structures (Wilson et al., 2016). Some economies quickly adopted the laws but acceptance and implementation of new steps toward the free market are shown to be quite problematic. Those who need to provide help for entrepreneurs have become corrupted. Some viable and functional firms are being destructed and new-formed SMEs were not being able to functionally integrate into the market economy. Other economies, although had some resistance to market changes, made significant and successful breakthroughs towards liberal markets. The SMEs had been establishing progressively, with enough time to organize in the manner of market orientation and with greater chances for successful operating (McIntyre, 2001). The analysis of the success and failure of SMEs during the transition period should consider development level of political, economic and social systems with new market relationships and private ownerships.

The transition is a process that differs from country to country and faces different conditions in the surrounding. The changes are being made in the political, institutional and economic areas and trigger the creation of a wide range of business structures (Wilson et al., 2016). Some economies quickly adopted the laws but acceptance and implementation of new steps toward the free market are shown to be quite problematic. Those who need to provide help for entrepreneurs have become corrupted. Some viable and functional firms are being destructed and new-formed SMEs were not being able to functionally integrate into the market economy. Other economies, although had some resistance to market changes, made significant and successful breakthroughs towards liberal markets. The SMEs had been establishing progressively, with enough time to organize in the manner of market orientation and with greater chances for successful operating (McIntyre, 2001). The analysis of the success and failure of SMEs during the transition period should consider development level of political, economic and social systems with new market relationships and private ownerships.

\section{THEORETICAL FRAMEWORK AND DEVELOPMENT OF HYPOTHESES}

The research in this area can be quite difficult since owners and managers of 
disappeared SMEs are hard to reach and convince to express their opinion toward the topic. Despite that many pieces of research have been done, many questions have still remained unanswered.

In dealing with the topic, the first is to define business failure. The business failure can be interpreted in different ways: as financial distress that leads to bankruptcy and closing; the significant turnaround in business that means a complete change of activity; natural end to the life cycle of a business project, or withdrawal because of some subjective or objective reasons (Pretorius, 2009; Amankwah-Amoah, 2016; Tobback et al., 2017; Mihajlović \& Stojanović, 2019). In this research business failure was treated as distress that leads to bankruptcy and closing but also a change of business activities.

The researchers extensively investigate the reasons for SME failure and try to establish models for failure prediction as well as factors that can be recognized in the earliest possible moment in order to prevent and overcoming distress. Some authors pointed that financial distress and lack of capital are the main reason for business failure (Hutchinson \& Xavier, 2006). There is a large group of authors who believe that not only the financial factors are crucial for success or failure of one business (Shafique et al., 2011). Also, only one or even a few factors can't be observed as responsible for the failure of the business. This issue should be considered as a splice of conditions, circumstances, and characteristics with their interrelations (Ropega, 2011). In this study, the focus is on several factors that are considered to have great influence on business failure and recovery.

\subsection{Personal factors}

Failure of one SME can occur in any phase of the business life cycle but as statistics show most of the problems appears at the beginning, in the first 2 - 5 years (Eurostat, 2018; U.S. Small Business Administration, 2018). Nikolić et al. (2018), in their research, pointed out two main groups of SMEs failure factors. To one group belong individual factors where the personal characteristics of entrepreneurs and owners were being considered and motivation for starting SMEs. Another group was nonindividual factors consisted of internal, had referred business organization, climate, and culture, and external had referred political, economic, social, technological, environmental, legal and infrastructural issues.

Prior to establishing a business, the motives of the entrepreneur have to be questioned (Veličković, 2019). It is more likely that solid and ground-based motives can contribute to better and proactive pursuing the business opportunities, the orientation toward market needs, understanding the competitors, commitment to more innovative or traditional ways of doing business, quantity and severity of the risks taken, etc. In addition, with the right motives, a potential entrepreneur has the possibility to exploit own prior experience in a way to compensate lacks in other features. (Nikolić et al., 2018) showed that motivation has considerable influence on the level of recovery after the failure. Besides motivation for establishing a business, personal factors are recognized as dominant factors for failure (Jovanović et al., 2018). The essential premise in the numerous researches is that chances for one SME to succeed or fail depend on entrepreneur features as the main 
decision and strategy makers (Ropega, 2011). In this light, the first hypothesis was defined:

H1: Underdeveloped personal characteristics of entrepreneur has influence on business failure

\subsection{Internal factors}

Internal factors are affected by the owner's or manager's ability to establish and keep up a sustainable SME. Those factors are partially controllable and include the competencies and assets of SME as well as managerial style that was established and used in solving emerging problems. Swift demand changes burden the SMEs from organizational and strategically points as well as operational. Regarding that, it is needed careful strategy formulation, opportunities seizing, competitors monitoring, human resource management and establishment of the flexible supply chains (Rakesh, 2014). Although this might look like as an external issue, it is closely related to poor managerial skills (Fatoki, 2014), lack of management attention to human resource management, lack of capital and financial management, marketing strategy, strategy in general and operations shortcomings (Hove \& Tarisai, 2013). Entrepreneurs often do not have managerial practice or knowledge before starting a business, therefore they develop their own managerial style and organizational structure of the firm. They are more concerned with short term gains than long term planning and developing business strategies (Kamunge et al., 2014).

One of the major challenges in managing SMEs is the level of available financial assets as well as access to finances (Mazanai
\& Fatoki, 2012). Lack of finances is a huge problem in transitional economies due to the undeveloped market and weak interest of banks to finance SMEs (Wang, 2016), high costs and short time of the loan and high fees and taxes. Also, the term SMEs stands for a large scale of businesses with substantial diversity within SMEs in a number of employees, management style, financial and material assets, and possibilities to access to banks and financial institutions (Kalak \& Hudson, 2016). The treatment in creditors' institutions is distinctly connected with the size of the firm and financial risk assessments (Gupta et al., 2015; Kalak \& Hudson, 2016). Researches showed that businesses of different sizes carry different insolvency risks because the creditors are more severe in debt claims toward the firms with higher asset sizes (Altman et al., 2010). Insufficient finances diminish possibilities for SMEs for acquisition and acceptance of new technologies, and implementation of innovative solutions (Kamunge et al., 2014). Other constraints concerning finances are organizing effective supply chains, procurement, and liabilities. In accordance with the previous statements, the following hypothesis was formulated:

H2: Deficiency in internal factors affects business failure

\subsection{External factors}

The entrepreneur needs a proactive approach concerning external factors since the possibility of substantial influence is very limited and those factors can be vital for the survival of SMEs. At first, successful SMEs is necessary to emphasize the importance of institutions. Governments in attempts to help SMEs should rather focus on building 
appropriate surroundings for SME growing instead of some kind subsidizing. This means the development of the legal system, financial sector, better information sharing, the ease of doing business, decreasing of bureaucracy and establishment regulation (Beck et al., 2006; Klapper et al., 2006; The World Bank, 2019a).

The entrepreneur needs a proactive approach concerning external factors since the possibility of substantial influence is very limited and those factors can be vital for the survival of SMEs. At first, successful SMEs is necessary to emphasize the importance of institutions. Governments in attempts to help SMEs should rather focus on building appropriate surroundings for SME growing instead of some kind subsidizing. This means the development of the legal system, financial sector, better information sharing, the ease of doing business, decreasing of bureaucracy and establishment regulation (Beck et al., 2006; Klapper et al., 2006; The World Bank, 2019a).

Business and society are interconnected in many ways. Socio-cultural factors are strongly related to the business environment because of traditions, religion, beliefs, and affiliation. Socio-cultural, demographic and environmental factors are serious questions for SMEs since they influence the habits of consumers, workforce eligibility, size of the targeted market. SMEs have to focus on specific market segments with particular needs or else can find themselves in the threat of not following consumption behavior and experience serious operating problems. From the SME owner's aspect, social factors presuppose relationships among business partners, attitude to risk, management style and business ethics (Johnson et al., 2014). The following hypothesis was formulated based on previous statements:

H3: External factors can have a substantial influence on business failure

A conceptual model comprising hypothesized relations is presented in Figure 1.

\section{METHODOLOGY}

\subsection{Sample and Data Collection}

This research was conducted during 2018-2019 using the questionnaire developed by a team of scientists and

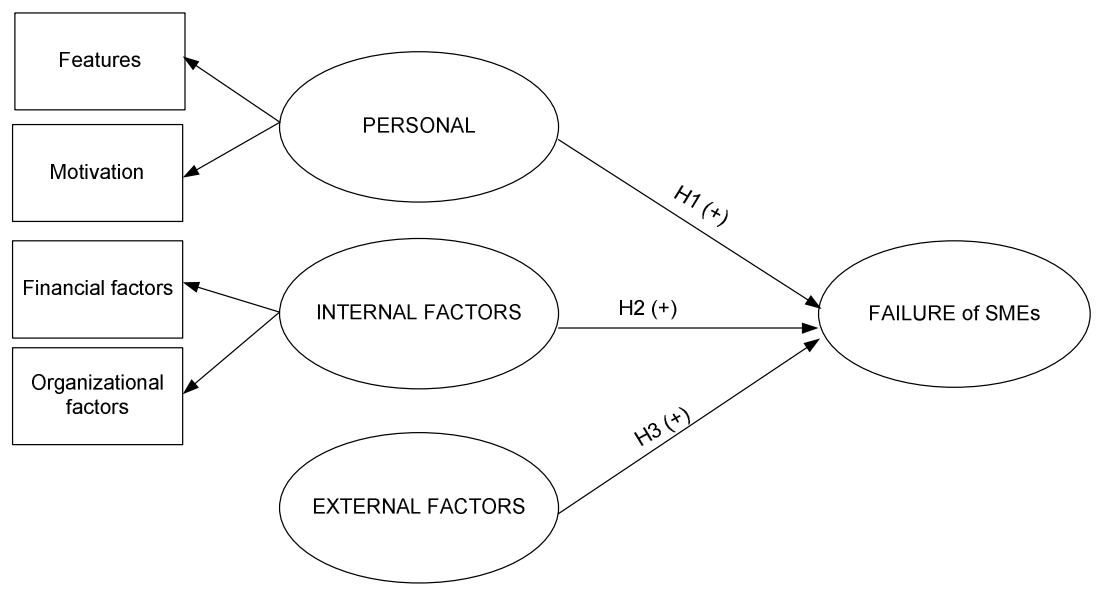

Figure 1. Conceptual model 
scholars from Visegrad countries (Hungary, Czech Republic, Slovakia, and Poland) and the Republic of Serbia, participants in joint research, and using the available literature on the topic. The questionnaire consisted of 51 open and closed questions, divided into several categories. The advantage of using the questionnaire is that it provides anonymity of respondents, the discretion of data and the total standardization of collected data. For answer gradation, Likert's fivepoint scale, where 5 stand for "I fully agree" and 1 stands for "I fully disagree" was used.

The studied population consisted of entrepreneurs and managers of failed businesses. The study focused on small and medium sized enterprises, therefore it was quite challenging to collect an adequate number of respondents. In this paper, the data from the three countries were being used for the analysis. A total of 329 properly filed questionnaires were collected wherefrom the Republic of Serbia 134, Hungary 100 and the Czech Republic 95. The profile of respondents and firms are presented in Table 1.

\subsection{Measures}

This questionnaire is designed to measure different aspects of the entrepreneur's personality, capabilities, experience, and assets of the SME as well as the elements that are not under the direct influence. After conducting Exploratory Factor Analysis (EFA) on all questions, the questions that describe the variables of interest were derived. The results of the EFA are presented in Table 2.

The motivation for starting a business was examined through questions about the necessity for self-fulfillment, the need to be satisfied with the job and the possession of a good network of acquaintances that can

Table 1. Profile of respondents and firms

\begin{tabular}{|c|c|c|c|c|c|c|c|}
\hline & & \multicolumn{2}{|c|}{ Serbia } & \multicolumn{2}{|c|}{ Hungary } & \multicolumn{2}{|c|}{ Czech Republic } \\
\hline & & Freq & Perc & Freq & Perc & Freq & Perc \\
\hline \multirow{5}{*}{ Age } & Less than 25 & 3 & 2.2 & 6 & 6.0 & 6 & 6.3 \\
\hline & $26-35$ & 27 & 20.1 & 16 & 16.0 & 11 & 11.6 \\
\hline & $36-45$ & 47 & 33.6 & 18 & 18.0 & 33 & 34.7 \\
\hline & $46-55$ & 32 & 23.9 & 37 & 37.0 & 28 & 29.5 \\
\hline & More than 56 & 27 & 20.1 & 23 & 23.0 & 17 & 17.9 \\
\hline \multirow{5}{*}{$\begin{array}{l}\text { Experience in related } \\
\text { sector }\end{array}$} & Less than 1year & 15 & 13.3 & 1 & 1.1 & 3 & 3.2 \\
\hline & $1-3$ years & 11 & 9.7 & 12 & 12.9 & 12 & 12.8 \\
\hline & $3-5$ years & 20 & 17.7 & 10 & 10.8 & 2 & 2.1 \\
\hline & $5-10$ years & 27 & 23.9 & 13 & 14.0 & 17 & 18.1 \\
\hline & More than 10 years & 40 & 35.4 & 57 & 61.3 & 60 & 63 \\
\hline \multirow{5}{*}{$\begin{array}{l}\text { Entrepreneurial } \\
\text { experience }\end{array}$} & Less than 1 year & 27 & 25.0 & 7 & 7.2 & 12 & 12.8 \\
\hline & $1-3$ years & 17 & 15.7 & 22 & 22.7 & 15 & 16.0 \\
\hline & $3-5$ years & 14 & 13.0 & 13 & 13.4 & 10 & 10.6 \\
\hline & $5-10$ years & 37 & 34.3 & 17 & 17.5 & 19 & 20.2 \\
\hline & More than 10 years & 13 & 12.0 & 38 & 39.2 & 38 & 40.4 \\
\hline \multirow{3}{*}{$\begin{array}{l}\text { Age of the company } \\
\text { in the period of } \\
\text { financial distress }\end{array}$} & Less than 3 years & 37 & 28.5 & 21 & 21.0 & 31 & 32.6 \\
\hline & 3 to 5 years & 26 & 20.0 & 25 & 25.0 & 7 & 7.4 \\
\hline & More than 5 years & 67 & 51.5 & 54 & 54.0 & 57 & 60.0 \\
\hline \multirow{4}{*}{ Number of employees } & Less than 10 & 101 & 78.9 & 77 & 77.0 & 69 & 72.6 \\
\hline & $11-50$ & 18 & 14.1 & 17 & 17.0 & 24 & 25.3 \\
\hline & $51-250$ & 6 & 4.7 & 6 & 6.0 & 1 & 1.1 \\
\hline & More than 250 & 3 & 2.3 & 0 & 0 & 1 & 1.1 \\
\hline
\end{tabular}


contribute to a successful business. A personal feature are being considered as a very important part of creating and running a successful business, therefore, was vital to examine self-assessments of respondents on this issue. The examined elements concerned self-confidence, need for accomplishment and creativity. These two factors made up one important influential factor named the Personal characteristics of an entrepreneur.

The financial aspect of the business, that had been investigated, encompassed delays in fulfilling bank obligations, the level of fixed assets free from any burden and the level of clearing/ barter transaction. Another issue that is influential on SMEs operating is an organization of the business. The difficulties in the absorption/acquisition of new technologies/innovation and the inability to find new potential partners are problems that entrepreneurs face and can lead to failure. The variable Internal factor encompasses these two factors.

Examined external factors had included political, economic and social issues. Finally, failure was observed through the personal perceptions of the respondents over the failure and impact on their personal life.

Table 2. Exploratory factor analysis

\begin{tabular}{|c|c|c|c|c|c|c|c|}
\hline \multirow{3}{*}{ 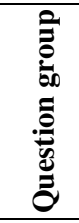 } & \multirow{3}{*}{ 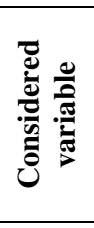 } & \multicolumn{6}{|c|}{ Exploratory factor analysis (EFA) } \\
\hline & & \multicolumn{2}{|l|}{$\begin{array}{l}\text { SERBIA } \\
\text { PCA }\end{array}$} & \multicolumn{2}{|c|}{$\begin{array}{l}\text { HUNGARY } \\
\text { PCA }\end{array}$} & \multicolumn{2}{|c|}{$\begin{array}{c}\text { CZECH REPUBLIC } \\
\text { PCA }\end{array}$} \\
\hline & & $\begin{array}{c}\text { KMO and \% of } \\
\text { variance } \\
\text { explained }\end{array}$ & $\begin{array}{l}\text { Factor } \\
\text { loading }\end{array}$ & $\begin{array}{c}\text { KMO and \% of } \\
\text { variance } \\
\text { explained }\end{array}$ & $\begin{array}{l}\text { Factor } \\
\text { loading }\end{array}$ & $\begin{array}{c}\text { KMO and \% of } \\
\text { variance } \\
\text { explained }\end{array}$ & $\begin{array}{l}\text { Factor } \\
\text { loading }\end{array}$ \\
\hline \multirow{6}{*}{ 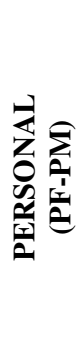 } & PF1 & \multirow{6}{*}{$\begin{array}{c}\text { KMO . } 793 \\
47.91 \%\end{array}$} & .656 & \multirow{6}{*}{$\begin{array}{c}\text { KMO .696 } \\
39.49 \%\end{array}$} & .628 & \multirow{6}{*}{$\begin{array}{c}\text { KMO .656 } \\
61.71 \%\end{array}$} & .525 \\
\hline & PF2 & & .673 & & .617 & & .595 \\
\hline & PF3 & & 619 & & .490 & & .647 \\
\hline & PM1 & & .710 & & .681 & & .771 \\
\hline & PM2 & & .751 & & .776 & & .614 \\
\hline & PM3 & & .735 & & .537 & & .551 \\
\hline \multirow{5}{*}{ 畜重 } & IF1 & \multirow{5}{*}{$\begin{array}{c}\text { KMO .765 } \\
50.55 \%\end{array}$} & .710 & \multirow{5}{*}{$\begin{array}{c}\text { KMO .720 } \\
47.36 \%\end{array}$} & .447 & \multirow{5}{*}{$\begin{array}{c}\text { KMO .679 } \\
72.38 \%\end{array}$} & .753 \\
\hline & IF2 & & 650 & & .656 & & .580 \\
\hline & IF3 & & 624 & & .752 & & .741 \\
\hline & IO1 & & .773 & & .785 & & .797 \\
\hline & $\mathrm{IO} 2$ & & .784 & & .746 & & .747 \\
\hline \multirow{3}{*}{ 彥 } & E1 & \multirow{3}{*}{$\begin{array}{c}\text { KMO .667 } \\
61.95 \%\end{array}$} & .761 & \multirow{3}{*}{$\begin{array}{c}\text { KMO .638 } \\
58.68 \%\end{array}$} & .798 & \multirow{3}{*}{$\begin{array}{c}\text { KMO .480 } \\
72.94 \%\end{array}$} & .731 \\
\hline & E2 & & .799 & & .794 & & .840 \\
\hline & E3 & & .800 & & .702 & & .617 \\
\hline \multirow{4}{*}{ 舁 } & $\mathrm{F} 1$ & \multirow{4}{*}{$\begin{array}{c}\text { KMO .764 } \\
60.84 \%\end{array}$} & .646 & \multirow{4}{*}{$\begin{array}{c}\text { KMO .699 } \\
54.07 \%\end{array}$} & .575 & \multirow{4}{*}{$\begin{array}{c}\text { KMO .693 } \\
66.58 \%\end{array}$} & .729 \\
\hline & $\mathrm{F} 2$ & & .837 & & .760 & & .817 \\
\hline & F3 & & .845 & & .775 & & .848 \\
\hline & F4 & & .776 & & .809 & & .863 \\
\hline
\end{tabular}




\section{DATA ANALYSIS AND RESULTS}

Measurement and structural models have been tested with software packages SPSS v.17 and AMOS v.8, using a structural equation model (SEM) (Byrne, 2004; Milošević et al., 2018). The data were estimated using the maximum likelihood method. In the first step, for examining the reliability and validity of the research model a measurement model was defined, on which confirmatory factor analysis (CFA) was performed.

However, the statistical method for testing measurement and structural invariance across groups was multigroup confirmatory factor analysis (MGCFA). Obtained data were processed and analyzed using the statistical analysis, where validation of the conceptual model (Figure 1) was achieved. As a result, statistical analysis multidimensionality was confirmed using exploratory factor analysis (EFA) for two groups of latent variables in the observed model and unidimensionality for two other groups of latent variables. However, it could be argued that there exists a causal relation between the two dimensions in these two

Table 3. Multigroup Confirmatory Factor Analysis (MGCFA) of the measurement model

\begin{tabular}{|c|c|c|c|c|c|c|c|c|c|c|}
\hline \multirow{3}{*}{ ن } & \multirow{3}{*}{ 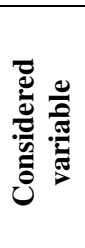 } & \multicolumn{9}{|c|}{ Confirmatory factor analysis (CFA) } \\
\hline & & \multicolumn{3}{|c|}{ SERBIA } & \multicolumn{3}{|c|}{ HUNGARY } & \multicolumn{3}{|c|}{ CZECH REPUBLIC } \\
\hline & & 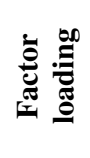 & 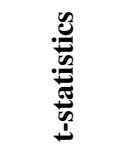 & 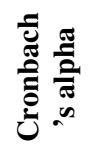 & 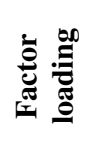 & 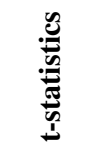 & 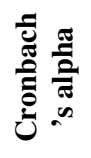 & 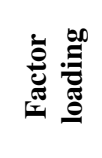 & 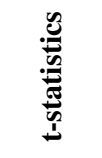 & 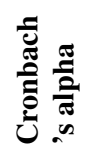 \\
\hline \multirow{6}{*}{ 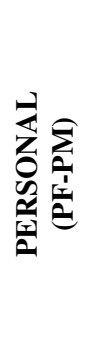 } & PF1 & 0.502 & 9.208 & \multirow{6}{*}{0.777} & 0.241 & 9.208 & \multirow{6}{*}{0.681} & 0.499 & 9.208 & \multirow{6}{*}{0.736} \\
\hline & PF2 & 0.867 & 12.427 & & 0.597 & 12.427 & & 0.865 & 12.427 & \\
\hline & PF3 & 0.555 & - & & 0.274 & - & & 0.551 & - & \\
\hline & PM1 & 0.720 & - & & 0.673 & - & & 0.719 & - & \\
\hline & PM2 & 0.743 & 11.778 & & 0.698 & 11.778 & & 0.742 & 11.778 & \\
\hline & PM3 & 0.625 & 13.252 & & 0.575 & 13.252 & & 0.624 & 13.252 & \\
\hline \multirow{5}{*}{ 离 } & IF1 & 0.580 & 10.129 & \multirow{5}{*}{0.752} & 0.529 & 10.129 & & 0.421 & 10.129 & \multirow{5}{*}{0.704} \\
\hline & IF2 & 0.849 & 12.908 & & 0.815 & 12.908 & & 0.724 & 12.908 & \\
\hline & IF3 & 0.812 & - & & 0.773 & - & 0.702 & 0.672 & - & \\
\hline & IO1 & 0.667 & 11.142 & & 0.638 & 11.142 & & 0.587 & 11.142 & \\
\hline & IO2 & 0.678 & - & & 0.650 & - & & 0.599 & - & \\
\hline \multirow{3}{*}{ 国 } & E1 & 0.552 & - & \multirow{3}{*}{0.683} & 0.425 & - & & 0.332 & - & \multirow{3}{*}{0.831} \\
\hline & E2 & 0.583 & 5.783 & & 0.454 & 5.783 & 0.640 & 0.356 & 5.783 & \\
\hline & E3 & 0.747 & 6.321 & & 0.623 & 6.321 & & 0.512 & 6.321 & \\
\hline \multirow{4}{*}{$\underbrace{\text { 点 }}_{\text {罗 }}$} & $\mathrm{F} 1$ & 0.861 & - & \multirow{4}{*}{0.785} & 0.848 & - & & 0.835 & - & \multirow{4}{*}{0.831} \\
\hline & $\mathrm{F} 2$ & 0.878 & 6.919 & & 0.867 & 6.919 & 0700 & 0.855 & 6.919 & \\
\hline & F3 & 0.969 & 6.885 & & 0.965 & 6.885 & & 0.962 & 6.885 & \\
\hline & F4 & 0.590 & 5.524 & & 0.568 & 5.524 & & 0.548 & 5.524 & \\
\hline
\end{tabular}


latent variables. The personal characteristics had been described by features and motivations of entrepreneurs, while the internal factors involved financial and organizational segments of business activities.

The structural equation model (SEM) was analyzed to confirm the reliability of the conceptual model, using multi-group confirmatory factor analysis (MGCFA) for comparative measurements on three samples from different countries, the Republic of Serbia, Hungary, and the Czech Republic.

In the first step measurement model was confirmed, where correlation matrix and reliability of the measuring scale were tested. In this purpose the maximum likelihood method was applied. Obtained values are very satisfying, indicating a good fit between the proposed model $\left(\chi^{2} S a t=785.5 ; d f=26\right.$; $\chi^{2}=3$ ). These results can be considered as significant because it fills up the requirement of being equally or less than 3 (Hoetler, 1983). Indices for model comparison such as RMSEA $=0.045$; IFI $=0.904, \mathrm{CFI}=0.900$ are close or higher than 0.9 (Hoetler, 1983), that indicators of the fitting show a satisfactory level of the measurement model. Cronbach's alphas were calculated for the Serbian, Hungarian and Czech groups of respondents. In the existing sample, the internal consistency was good for the Republic of Serbia $(\alpha=0.741)$, Hungary $(\alpha=0.694)$ and the Czech Republic $(\alpha=0.741)$, while the internal consistency across groups of questions for each examined country is depicted in Table 3 (Cronbach, 1951).

Table 4 depicts the relationships between personal, internal, external factors as well as factors of business failure. Given that the three samples differed across various countries, these constructs were controlled in the correlational analysis.

\subsection{Multi-group analysis of structural models}

While the measurement model determines relationships between the observed variables and their factors, the structural model

Table 4. Correlation matrix of the groups of variables

\begin{tabular}{|c|c|c|c|c|c|}
\hline & & PERSONAL & INTERNAL & EXTERNAL & FAILURE \\
\hline \multirow{3}{*}{ 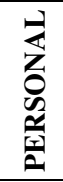 } & Republic of Serbia & & & & \\
\hline & Hungary & 1 & & & \\
\hline & Czech Republic & & & & \\
\hline \multirow{3}{*}{ 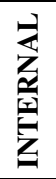 } & Republic of Serbia & 0.016 & & & \\
\hline & Hungary & 0.198 & 1 & & \\
\hline & Czech Republic & 0.179 & & & \\
\hline \multirow{3}{*}{ 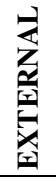 } & Republic of Serbia & 0.132 & 0.139 & & \\
\hline & Hungary & 0.155 & $0.333^{* *}$ & 1 & \\
\hline & Czech Republic & $0.367 * *$ & $0.423^{* *}$ & & \\
\hline \multirow{3}{*}{ 䆓 } & Serbia & $0.239^{*}$ & 0.02 & -0.012 & \\
\hline & Hungary & $0.250^{*}$ & $0.273^{*}$ & 0.077 & 1 \\
\hline & Czech Republic & 0.076 & $0.432 * *$ & $0.368 * *$ & \\
\hline
\end{tabular}


specifies the interrelated causal relationships among the constructs (Anderson \& Gerbing, 1988). In this case, the next step is factor variances that are examined to establish the equality of the relationship between latent factors (structural invariance). As Confirmatory Factor Analysis, parameter estimates for the structural model were processed by using the maximum likelihood analysis of the covariance matrices for the 18 observed variables. The overall fit of this model is adequate, with a $\chi^{2}$-statistic of 789.5 at 261 degrees of freedom $(p<0.001)$, RMSEA of 0.045 , a CFI of 0.900 and IFI of 0.904. Obtained values of the fit indexes indicate good empirical support of the structural model.

Figure 2 and Table 5 summarizes the SEM results of the proposed path model. Values depicted in Figure 2 are standardized path coefficients upon which hypothesis testing was based. Also, Panel 1 in Figure 2 reported the beta coefficient and $t$ values of Serbian samples, while Panel 2 shows the results of Hungarian respondents and Panel 3 depicts the beta coefficient and $t$ - values on the Czech sample.

A graphical representation of the assessed structural model for all three groups is provided in Figure 2. A review of Figure 2 exposes that patterns of structural relationships among the constructs are consistent between all those three groups, however, the value and statistical significance of path coefficients for the relationships, where the proposed hypotheses were tested, are different across groups.

Consistent with our theoretical predictions and literature, we found a significant and positive association between weak personal factors and failure of SMEs among Serbian entrepreneurs (path coefficient $\beta=0.401, \quad p<0.001)$, between internal factors and failure among Hungarian entrepreneurs (path coefficient $\beta=0.25$, $p<0.05$ ), between external factors and failure also among Hungarian respondents (path coefficient $\beta=0.204, p<0.05$ ) (Kadocsa \& Francsovics, 2011), and between internal factors and failure among Czech entrepreneurs (path coefficient $\beta=0.177$, $p<0.001)$.

\section{DISCUSSION}

As depicted in Panel A of Figure 2, only one path coefficient was found to be positive and statistically significant for the Serbian group of respondents. For observed H2 and $\mathrm{H} 3$, the value and significance of those effects were generally low, compared with those from the Hungarian and Czech groups of respondents. Specifically, the direct linkage between Internal factors and failure are considerably weak, while the relationship between external factors and failure has a negative direction without statistical significance at the 0.05 level, which suggests that $\mathrm{H} 2$ and $\mathrm{H} 3$ cannot be accepted for a group of Serbian respondents. Considering, the bad managerial ability and low entrepreneurial experience because of the late transition in the Republic of Serbia, SMEs face weakness in creating organizational structures as well as managing financial resources that lead to failure. Hypothesis 2 confirms this fact and as such cannot be fully rejected because has a positive direction. However, hypothesis 3 is absolutely rejected and it is in a negative direction, because Serbian entrepreneurs think that external factors do not affect their businesses.

Panel B of Figure 2 shows estimates of 
Panel A: Serbian SMEs (N=134)

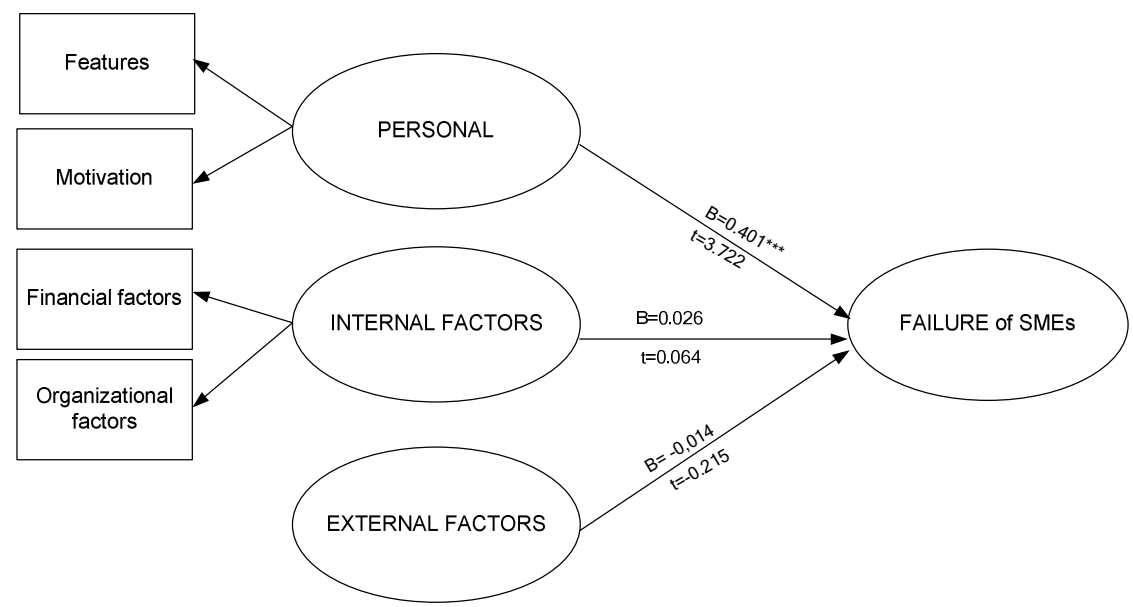

Panel B: Hungarian SMEs (N=100)

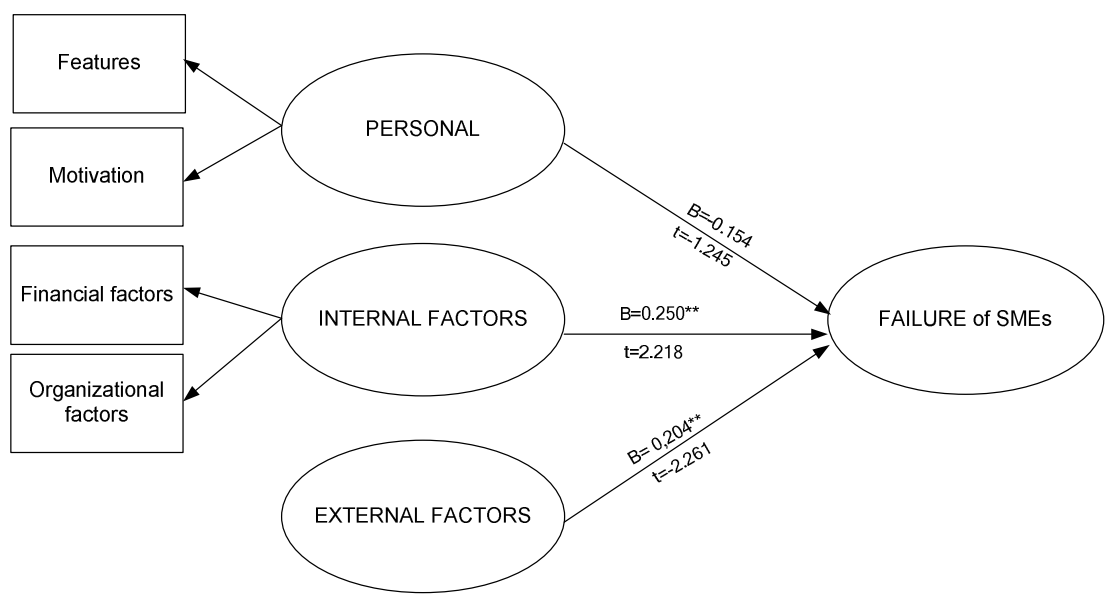

Panel C: Czech SMEs (N=95)

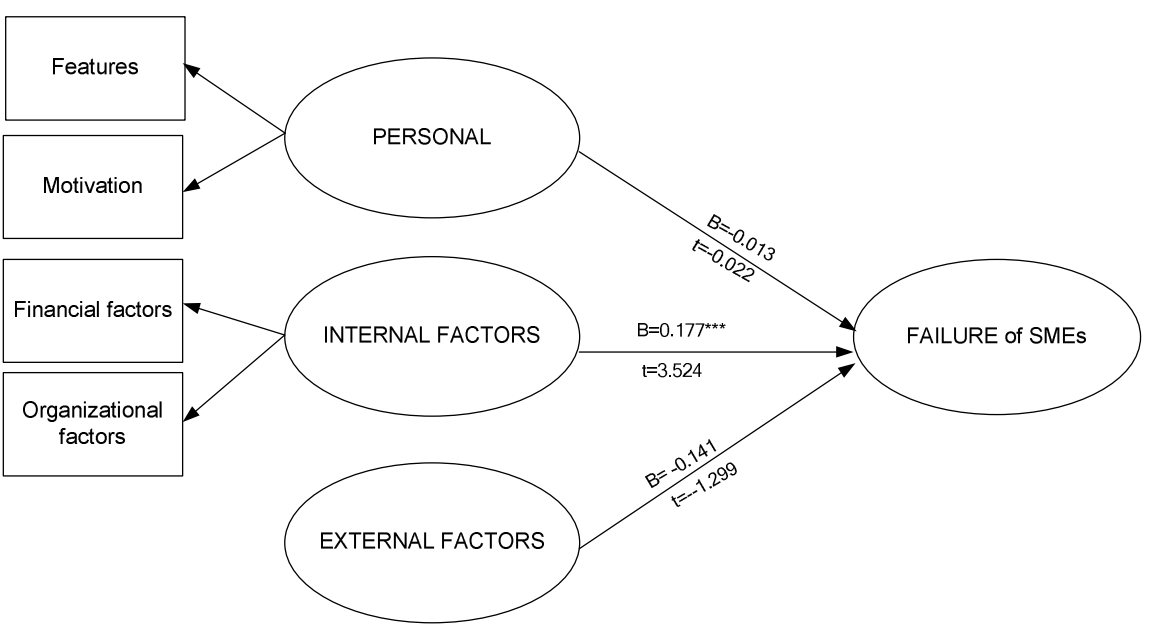

Figure 2. Structural model 
Table 5. Path Analysis of all examined group

\begin{tabular}{ccccccc}
\hline \multirow{2}{*}{ Construct } & \multicolumn{2}{c}{ Serbia } & \multicolumn{2}{c}{ Hungary } & \multicolumn{2}{c}{ Czech Republic } \\
& $\boldsymbol{\beta}$ & t-value & $\boldsymbol{\beta}$ & t-value & $\boldsymbol{\beta}$ & t-value \\
\hline Personal-Failure & $0.401^{* * *}$ & 3.722 & -0.154 & -1.245 & 0.03 & 0.022 \\
Internal- Failure & 0.026 & 0.064 & $0.250^{* *}$ & 2.218 & $0.177^{* * *}$ & 3.524 \\
External- Failure & -0.014 & -0.215 & $0.204 * *$ & 2.261 & -0.141 & -1.299 \\
\hline Note: *** significance level of $\mathrm{p}<0.001$ & & & & &
\end{tabular}

the parameter for the Hungarian group of respondents and shows that two proposed paths are significant in the expected direction. Based on the obtained values for $\mathrm{H} 2$ and $\mathrm{H} 3$ can be concluded that these two hypotheses are confirmed. Further, the direct linkage between personal factors and failure has a negative direction and no statistical significance, that this hypothesis is not supported. It can be concluded that Hungarian entrepreneurs believe that underdeveloped personal characteristics of entrepreneurs are not necessarily the cause of failure, already numerous external and internal factors should be considered.

In Panel $\mathrm{C}$ of Figure 2 can be seen that only one hypothesis has positive value with high significance for the Czech group of respondents, where $\mathrm{H} 2$ can be accepted. Direct linkages between personal and external factors with failure are not statistically significant, and those two hypotheses $(\mathrm{H} 1, \mathrm{H} 3)$ are rejected. When observed hypothesis 3 can be noticed that Czech entrepreneurs assume that political, economic and social factors do not have negative effect on their businesses. Considering that the Czech Republic is a country with the most developed market economy among examined countries these results are expected.

After reviewing the results from Panels A, $\mathrm{B}, \mathrm{C}$ can be noticed that exist significant differences between the three examined countries. The reason for these obtained results is a unique economic situation of each country, level of political stability and level of managerial awareness over entrepreneurship.

\section{CONCLUSION}

In this research, the focus is on failed SMEs which faced different obstacles on their managing of business activities. Factors which supposed to have an influence on business failure were examined and countries covered in the research are the Republic of Serbia, Hungary and the Czech Republic. In those three countries, a comparative analysis was performed, and certain conclusions were derived. For data processing, multigroup confirmatory factor analysis was conducted and some differences in the business failure factors in SMEs among those three countries were detected.

The Republic of Serbia is not a member of the European Union but it is a developing country with an overall environment that still cannot be characterized as fully SMEs favorable. Numerous external and internal factors cause degradation in the business performances of SMEs and lead to their failure. As the major internal weakness of SMEs was considered the lack of capital that 
can be the main reason for financial distress and business failure (Hutchinson \& Xavier 2006) and entrepreneurs indicated the importance of this factor. Bobić, (2017) sets apart the role of the state, unpredictable business environment and lack of institutional protection, among other external factors as major obstacles in running a business in Serbia. However, the results of this research pointed out that entrepreneurs are still turning to themselves as the main factor influencing unsuccessful business (Veličković, 2019), and diminish the influence of business surrounding. At this point Serbia differs from the other two examined countries which, through literature and research results, emphasized the importance of other factors than personal, for SME success (Çera et al., 2019; Majláth, 2019).

The paper offers a few contributions to understanding the topics of SMEs failures in the Republic of Serbia. First, the academic interest in Serbia, based on available literature is very modest therefore paper provides an additional perspective over the SMEs failure problem. For entrepreneurs, it directs attention on points that should be avoided in order to prevent business failure and indicates safe steps that can be followed i.e. fields in which improvement should be made for the success of one SME.

\section{Acknowledgement}

This paper was supported by the International Visegrad Fund, project number 21820267, titled "How to prevent SMEs failure (Actions based on comparative analysis in Visegrad countries and Serbia)”.

\section{References}

2018 SBA Fact Sheet Czech Republic. (2019, October 1). European Commission. Preuzeto sa ec.europa.eu: https:/ec.europa.eu/docsroom/documents/32 581/attachments/7/translations/en/renditions /native

2018 SBA Fact Sheet Hungary. (2019, October 1). European Commission. Preuzeto sa

ec.europa.eu: https:/ec.europa.eu/docsroom/documents/32 581/attachments/14/translations/en/rendition s/native

2018 SBA Fact Sheet Serbia. (2019, October 1). European Commission. Preuzeto $\mathrm{sa}$ ec.europa.eu: https://ec.europa.eu/neighbourhoodenlargement/sites/near/files/sba-fs2018_serbia.pdf

Altman, E. I., Sabato, G., \& Wilson, N. (2010). The value of non-financial information in small and medium-sized enterprise risk management. Journal of Credit Risk, 6 (2), 95-127.

Amankwah-Amoah, J. (2016). An integrative process model of organisational failure. Journal of Business Research, 69 (9), 3388-3397.

Anderson, J.C., \& Gerbing, D.W. (1988). Structural equation modeling in practice: A review and recommended two-step approach. Psychological Bulletin, 103 (3), 411-423.

Beck, T., Demirgüç-Kunt, A., \& Maksimovic, V. (2006). The Influence of Financial and Legal Institutions and Firm Size. Journal of Banking and Finance, 30 (11), 2995-3015.

Bobić, D. (2017). Youth entrepreneurship in Serbia, Mapping barriers to youth entrepreneurship. Center for Advanced Economic Studies Belgrade, Serbia. 


\title{
ДОМИНАНТНИ ФАКТОРИ НЕУСПЕХА МСП - МУЛТИГРУПНА КОНФИРМАТОРСКА ФАКТОРСКА АНАЛИЗА
}

\author{
Исидора Милошевић, Иван Михајловић, Анђелка Стојановић
}

\section{Извод}

Овај рад има за циљ да пружи емпиријско појашњење неких кључних фактора неуспеха малих и средњих предузећа (МСП), као и анализу сличности и разлика у односима између фактора у Републици Србији и Вишеград земљама. Факторима неуспеха МСП-а приступа се са становишта власника и менаџера МСП-а чија су мишљења прикупљена путем упитника који је дистрибуиран у пет земаља (Мађарска, Чешка, Словачка, Пољска и Република Србија). С друге стране, за истраживање представљено у овом раду коришћени су подаци из Мађарске, Чешке и Републике Србије. Модел структурних једначина је развијен и анализиран како би се потврдила поузданост концептуалног модела, користећи мулти-групну конфирматорну факторску анализу (МГКФА) за упоредна мерења на разматраним подацима из различитих земаља. Резултат је показао постојање разлика у мишљењима власника и менаџера малих и средњих предузећа о факторима неуспеха у испитиваним земљама.

Кључне речи: мала и средња предузећа, фактори неуспеха, мулти-групна анализа

Byrne, B. M. (2004). Testing for multigroup invariance using AMOS graphics: A road less traveled. Structural Equation Modeling, 11 (2), 272-300.

Çera, G., Belás, J., \& Hrušecká, D. (2019). SMEs Performance and the Major Obstacles of SMEs Growth in Czech Republic. In Mihajlović, I. (Ed). How to prevent SMEs failure (Action based on comparative analysis in Visegrad countries and Serbia) Technical Faculty in Bor. Bor, Serbia. 29-45.

Cronbach, L.J. (1951). Coefficient alpha and the internal structure of tests. Psychometrika, 16 (3), 297-334.

Culkin, N., \& Simmons, R. (2018). Study of the challenges that hinder MSME development in the Republic of Serbia. British Council.

Eurostat. (2018, November 29). Business demography by size class (from 2004 onwards, NACE Rev. 2). Retrieved January 22, 2019, from http://appsso.eurostat.ec.europa.eu/nui/subm itViewTableAction.do

Fatoki, O. (2014). The Causes of the Failure of New Small and Medium Enterprises in South Africa. Mediterranean Journal of Social Sciences, 5 (20), 922-927.

Gupta, J., Gregoriou, A., \& Healy, J. (2015). Forecasting bankruptcy for SMEs using hazard function: to what extent does size matter. Review of Quantitative Finance and Accounting, 45 (4), 845-869.

Guptaa, J., \& Gregoriou, A. (2018). Impact of market-based finance on SMEs failure. Economic Modelling, 69 (C), 13-25.

Hoetler, J.W. (1983). The analysis of covariance structures: Goodness of fit indices. Sociological Methods and Research, 11(3), 325-344.

Hove, P., \& Tarisai, C. (2013). Internal Factors Affecting the Successful Growth and Survival of Small and Micro Agri-business Firms in Alice Communal Area. Journal of Economics, 4 (1), 57-67. 
Hutchinson, J., \& Xavier, A. (2006). Comparing the impact of credit constraints on the growth of SMEs in a transition country with an established market economy. Small Business Economics, 27 (2-3), 169-179.

Johnson, F., George, O., Owoyemi, O., \& Adegboye, M. (2014). Effects of SocioCultural Realities on the Nigerian Small and Medium Sized Enterprises (SMEs): Case of Small and Medium Sized Enterprises in Lagos State. International Journal of Business and Management; 9 (1), 90-100.

Jovanović, I., Arsić, M., \& Nikolić, Đ. (2018). Entrepreneurial personality traits and SMEs profitability in transition economy. Serbian Journal of Management 13 (1), 89104.

Kadocsa, G., \& Francsovics, A. (2011). Macro and micro economic factors of small enterprise competitiveness. Acta Polytechnica Hungarica, 8 (1), 23-40.

Kalak, I., \& Hudson, R. (2016). The effect of size on the failure probabilities of SMEs: An empirical study on the US market using discrete hazard model. International Review of Financial Analysis, 43 (January), 135-145.

Kamunge, M., Njeru, A., \& Tirimba, O. (2014). Factors Affecting the Performance of Small and Micro Enterprises in Limuru Town Market of Kiambu County, Kenya. International Journal of Scientific and Research Publications, 4 (1), 1-19.

Klapper, L., Laeven,L., \& Rajan, R. (2006). Entry Regulation as a Barrier to Entrepreneurship. Journal of Financial Economics, 82 (3), 591-629.

Majláth, M. (2019). Reasons of failure of SMEs in Hungary. In Mihajlović, I. (Ed). How to prevent SMEs failure (Action based on comparative analysis in Visegrad countries and Serbia). Technical Faculty in Bor. Bor, Serbia. 6-29.
Mazanai, M., \& Fatoki, O. (2012). Access to Finance in the SME Sector: A South African Perspective. Asian Journal of Business Management, 4 (1), 58-67.

McIntyre, R. (2001). The Role of Small and Medium Enterprises in Transition: Growth and Entrepreneurship. UNU/WIDER. Helsinki, Finland.

Mihajlović, I., \& Stojanović, A. (2019). How to address and understand the failure of SMEs: framework and factors. In Mihajlović, I. (Ed). How to prevent SMEs failure (Action based on comparative analysis in Visegrad countries and Serbia). Technical Faculty in Bor. Bor, Serbia. 663694.

Milošević, I., Trajković, A., Rajić, T., Nikolić, Đ., \& Arsić, S. (2018). The effects of quality certification in establishing and developing customer - supplier relationships. Serbian Journal of Management, 13 (1), 115131.

Nikolić, N., Jovanović, I., Nikolić, Đ., Mihajlović, I., \& Schulte, P. (2018). Investigation ofthe Factors Influencing SME Failure as a Function of Its Prevention and Fast Recovery after Failure. Entrepreneurship Research Journal, 9 (3), 121.

Pretorius, M. (2009). Defining business decline, failure and turnaround: a content analysis. The Southern African Journal of Entrepreneurship and Small Business Management, 2 (1), 1-16.

Rakesh, C. (2014). PEST Analysis for Micro Small Medium Enterprises Sustainability. Journal of Management and Commerce, 1 (1), 18-22.

Ropega, J. (2011). The Reasons and Symptoms of Failure in SME. International Advances in Economic Research. 17 (4), 476-483.

Shafique, M., Rizwan, M., Jahangir, M., 
Mansoor, A., Akram, S., \& Hussain, A. Technical Faculty in Bor. Bor, Serbia. 171(2011). Determinants of entrepreneurial 191.

success/failure from SMEs perspective. IOSR Journal of Business and Management, 1 (special issue), 83-92.

The World Bank. (2017, June 28). Helping Small Businesses Handle Insolvency: World Bank Group Report Insolvency Treatment. Retrieved from The World Bank: https://www.worldbank.org/en/news/feature/ 2017/06/28/helping-small-businesseshandle-insolvency-world-bank-groupreport-insolvency-treatment

The World Bank. (2019a, September 20). DOING BUSINESS, Measuring Business Regulations. Retrieved from The World $\begin{array}{lllll}\mathrm{B} & \mathrm{a} & \mathrm{n} & \mathrm{k} & \text { : }\end{array}$ https://www.doingbusiness.org/en/data/expl oreeconomies/serbia\#DB_sb

The World Bank. (2019b, September 20). Small and Medium Enterprises (SMES) Finance. Retrieved from The World Bank: https://www.worldbank.org/en/topic/smefina nce

Tobback, E., Bellotti, T., Moeyersoms, J., Stankova, M., \& Martens, D. (2017). Bankruptcy prediction for SMEs using relational data. Decision Support Systems, 102, 69-81.

U.S. Small Business Administration. (2018, August). Frequently Asked Questions About Small Business. Preuzeto sa a d v o c a c y. s b a. g o v : https://www.sba.gov/sites/default/files/advo cacy/Frequently-Asked-Questions-SmallBusiness-2018.pdf.

Veličković, M. (2019). The analysis of start up motives and barriers for entrepreneurship in Eastern Serbia. In Mihajlović, I. (Ed.). How to prevent SMEs failure (Action based on comparative analysis in Visegrad countries and Serbia).
Wang, Y. (2016). What are the biggest obstacles to growth of SMEs in developing countries? - An empirical evidence from an enterprise survey. Borsa Istanbul Review, 16 (3), 167-176.

Wilson, N., Ochotnický, P., \& Káčer, M. (2016). Creation and destruction in transition economies: The SME sector in Slovakia. International Small Business Journal, 34 (5), 579-600. 